\title{
Marketing Public Relations Program (MPR) for Creating the Brand Image of PELNI Jakarta Hospital
}

\author{
Tri Puspito Sari \\ Communication Department \\ Bina Nusantara University \\ Jakarta, Indonesia \\ tripuspitasari1428@gmail.com
}

\author{
Muhamad Aras \\ Communication Department \\ Bina Nusantara University \\ Jakarta, Indonesia \\ maras@binus.edu
}

\begin{abstract}
This study aims to determine the Marketing Public Relations program of PELNI Jakarta Hospital for creating the brand image of the hospital. The research approach used was descriptive qualitative. Research data were collected through direct observations and in-depth interviews with the Marketing Public Relations division of PELNI Jakarta Hospital. The results showed that the program carried out by Marketing Public Relations of PELNI Jakarta Hospital for creating the brand image was divided into various activities such as events, social media campaign, , evaluation, customer relations, making visits to providers, providing contact information, sponsorship or filling out health talk shows and providing free health checks, promotions, and advertising. All of these programs are carried out continuously by Marketing Public Relations of PELNI Jakarta Hospital to create a brand image.
\end{abstract}

Keywords: Marketing Public Relations, Brand Image, Hospital Program

\section{INTRODUCTION}

PELNI Hospital is a type B hospital located in West Jakarta. In the era of JKN (State Health insurance), PELNI Hospital has cooperated with some state-owned enterprises, namely BPJS Kesehatan (social security organizing body) and Employment BPJS to assist the government in providing good health services. In 2014, PELNI Hospital joined the BPJS for providing health insurance for the community. This increased the number of patients visiting the hospital, from 300 people to 1500 people every day. The health insurance used by patients is various, such as BPJS Health, Insurance, Corporate Guarantee, and personal payers. Based on data from the PELNI Hospital Medical Record in 2018, the percentage of patients who come is $86 \%$ of BPJS health patients, $14 \%$ of insurance patients, companies and general patients

The number of outpatients per day is up to 1500 people. In this case, Pelni Hospital has successfully become a pilot BPJS Guarantee Hospital in West Jakarta. In this situation, PELNI Hospital was only perceived as a BPJS hospital. This was supported by online news which explained Pelni Hospital's services for BPJS patients. In this case, PELNI Hospital must maintain their existence in their special health services to improve corporate, insurance and personal patients to increase company profits. PELNI Hospital must re-create the company's branding so that not only BPJS patients seek treatment at PELNI Hospital. In this case, the researchers will look at the concept of Marketing Public Relations in PELNI Hospital to recover the Brand Image of PELNI Hospital.

The function of Marketing Public Relations is to generate public awareness about the existence of company products [1]. This will certainly help create a new brand image for PELNI Hospital so that it can attract markets outside BPJS Health.

Keller (1993) in Rangkuti (2009) [2] proposes that brand image is a brand perception that is associated with brand associations inherent in consumer memory. Brand associations are information about brands given by consumers in their memory and contain the meaning of the brands. The impression that has been attached to the PELNI Hospital if left continuously will be increasingly attached to the consumer's mind

Marketing Public Relations is a combination of the power of public relations and marketing mix. The term Marketing Public Relations was first popularized by Thomas L. Harris through his book entitled The Marketer's Guide to Public Relations:

"Public Relations Marketing is the process of planning and evaluating programs, that encourages purchase and customer through credible communication and information identifying companies and their products with the needs, concerns of customer."

The above description implies that Marketing Public Relations is a process of planning and evaluating programs that stimulate sales and customers. This is done through communicating credible information and impressions that can connect the company, products to the needs and concerns of customers. The concept of Marketing Public Relations from Thomas L Harris is not much different from the definition proposed by Philip Kotler.

"Marketing Public Relations works because it adds value to products through its unique ability to lend credibility to product messages." 
From these definitions, it can be concluded that the Marketing Public Relations program is an attempt to stimulate (push) purchases and at the same time provide value or satisfaction for customers who have used their products.

Marketing Public Relations function was first discussed by Thomas L. Harris in his book The Marketer's Guide to Public Relations [1] mentioning the expansion of the public relations function to support the marketing objectives of an organization, forming the term Marketing Public Relations. Harris further explained that:

"In its market-support function, public relations is used ti achieving a number of objectives. The most important of those are raising awareness, to inform and educate, gain understanding, to build trust, to make friends, to give people reasons to buy and to create climate of consumer acceptance"

From Thomas L.Harris's explanation, it can further be explained that Marketing Public Relations has the following functions:

A. Generating public awareness about the existence of company products;

B. Provide information and education about the products;

C. Creating a harmonious atmosphere between consumers and products and companies;

D. Building trust between consumers and products.

Marketing Public Relations has an important role in the company to achieve the main goals of the organization (Kotler, 1993). In the book by the role of marketing Public Relations has the following roles, namely as described in the book [1]:

A. Growing consumer awareness of the product being launched.

B. Building consumer confidence in the company's image or the benefits or products offered.

C. Encouraging enthusiasm through a sponsor article about the uses and benefits of a product.

D. Suppressing the cost of commercial advertising promotion, both in electronic media and print media and so on in order to achieve customer satisfaction.

E. Improving service to consumers, including efforts to overcome complaints and so forth in order to achieve customer satisfaction.

F. Helping the campaign for the launch of new products and at the same time plans for changes in the old product position.

G. Communicating continuously through the public relations media about work activities and programs related to the social caring and environmental authenticity, so that a positive publication can be achieved.

$\mathrm{H}$. Fostering and maintaining the image of the company or goods as well services products, both in terms of quantity and quality of services provided to customers.

I. Proactively trying to deal with a negative event that might arise in the future.

While image is "the set of beliefs, ideas, and impressions a person holds regarding an object" [3]. Image of the company is public perception of the identity of the company. This perception is created based on information obtained about the company. This will affect the number of consumers' buying interest in the products or services produced by the company.

According to Kotler and Keller, [3] brand image is "the perceptions and beliefs held by customers, as reflected in the associations held in consumer memory".

Brand image is a series of associations that exist in the minds of consumers towards a brand, usually organized into a meaning. Relationships with a brand will be stronger if they are based on experience and information. Brand image is the overall impression in the minds of consumers formed from all sources. Consumers develop various associations with brands. Based on these associations, they form a brand image. The idea behind brand image is that consumers not only buy products or services but also images related to products or services. Brand image must be positive, unique and instant. Brand image can be strengthened by using brand communication such as advertising, packaging, word of mouth publicity, and other promotional tools. Brand image should be developed and product character should be conveyed in a unique way that is different from the competitors' images. Brand image consists of various associations in the minds of consumers, benefits and attributes. Brand attributes are functional and mental relationships with brands that customers have. They can be specific or conceptual [4].

Benefits are the rationale for purchasing decisions. There are three types of benefits: functional benefits - what you do better (than others), emotional benefits - how you make me feel better (than others), and rational benefits or support - why I believe you (more from the other). Brand image does not have to be created, but is automatically formed. Product brand image includes ease of use, functionality, fame, and overall value. Brand image is actually brand content. When consumers buy products, they also buy that image. Brand image is an objective and mental feedback from consumers when they buy a product. A positive brand image exceeds customer expectations. A positive brand image increases goodwill and brand value of an organization.

Consumers often buy products with wellknown brands because they feel more comfortable with things that are already known, the assumption that famous brands are more reliable, always available and easily searchable, and have undoubted quality, Consumers prefer brands they know rather than those that don't. 
According to Davis [5], brand image has two components, namely:

\section{A. Brand Associations}

The association of products and services that consumers attach to the brand, including consumer perceptions of promises made by the brand, positive and negative, and expectations about efforts to maintain customer satisfaction from the brand. A brand has strong roots when the brand is associated with values that represent or are desired by consumers. Brand associations help marketers understand the advantages of a brand that is conveyed to consumers.

\section{B. Brand Persona / Personality}

It refers to a series of human characteristics by consumers associated with the brand, such as personality, appearance, values, likes, gender, size, shape, ethnicity, intelligence, socio-economic class, and education. These things make the brand live and make it easier for consumers to describe it, as well as the determinants of whether consumers want to be associated with the brand or not.

According to Aaker and Biel [4], brand image has three components, namely:

A. Image maker (corporate image), which is a set of associations perceived by consumers to companies that make a product and service in this study which includes: popularity, credibility, and corporate networks.

B. User image (user image), which is a set of associations perceived by consumers to users who use goods or services, including the user itself, lifestyle, or personality, and social status.

C. Product image (product image), which is a set of associations perceived by consumers to a product, which includes the attributes of the product, benefits for consumers, users, and guarantees.

Based on this phenomenon, the purpose of this study was to examine the Public Relations Marketing Program (MPR) for creating the brand image of PELNI Jakarta Hospital

\section{RESEARCH METHODS}

This study provides a discussion about The brand image created by the public relations marketing program of PELNI Jakarta Hospital. Therefore, this study uses a qualitative method or approach, in which researchers explore and understand the meaning of each individual or group of people associated with the problem or phenomenon under study [6].

The research method used is a case study. Case study design is a design that explores real life and collects data in detail and in depth by involving several sources of information, as well as reporting research results descriptively [7]. Case study research provides an in-depth understanding of the object under study. Therefore, one data source is not enough. To develop an in-depth understanding of the object under study, the researchers collected various forms of qualitative data through interviews and observations [7].

In the process of collecting data, open interviews were conducted with several informants so that an understanding of the views, attitudes, feelings, and behaviour of individuals or groups of people were obtained [8]. In addition, the researchers provided a detailed explanation of the results of the theme analysis that has been carried out up to the reporting stage of the research results. Data analysis techniques used in this study consisted of open coding, axial coding, and selective coding [7]. Furthermore, for data validity, researchers used data source triangulation by making reductions, displays, and verification.

\section{RESULT}

PELNI Jakarta Hospital is a hospital that has been running for 100 years, located in West Jakarta, with type B hospital. It has been a plenary or five-star accredited hospital since 2017 . PELNI Hospital has an area of 3.2 hectares and has complete services to Type B hospital. The services available are 100 largest haemodialysis or dialysis services nationwide, cardiac care or Cat Lab, Medical Check-up with One Stop Service, 509 inpatient beds from grade 3 (three) to VVIP class, Endoscopy Centre, MRI 128 slide, MSCT, Radiology, 162 specialists, Emergency Emergency Unit, Beauty and Wellness Service, Policlinic Regular Service and Heritage Executive Polyclinic services. Patients in PELNI Jakarta Hospital use a number of guarantees, namely personal or self-paid, paid insurance, corporate guarantee and general insurance government programs for the community under the name BPJS (social security organizing body) with a percentage of use comparison of $86 \%$ BPJS and $14 \%$ non BPJS. PELNI Jakarta Hospital has been cooperating with BPJS Health Insurance since 2014 and PELNI Jakarta Hospital manages BPJS Patients well so that the number of BPJS patients can reach up to 1500 patients a day. This makes PELNI Jakarta Hospital have a Brand Image of BPJS hospital. This has Not clear here because there is a delay in payment from BPJS, making PELNI Jakarta Hospital turn its direction by increasing the number of its non-BPJS patients. From $20 \%$ in 2014 it is now $14 \%$.

Interviews were conducted with the Marketing Public Relations Division of Jakarta PELNI Hospital, involving informant A (Head of Marketing Public Relations of PELNI Jakarta Hospital) Informant B (Section Coordinator of Marketing Public Relations of PELNI Jakarta Hospital), Informant C (Section Staff Marketing Public Relations of PELNI Jakarta Hospital ). Based on the results of the interviews, the Marketing Public Relations strategy for creating the Brand Image of PELNI Jakarta Hospital is carried out through the following programs:

\section{A. Event}

One of the Public Relations Marketing programs of PELNI Jakarta Hospital for creating Brand Image is conducting events. Events carried out include annual events that must be followed every year and events in relation to national and international holidays in accordance with existing programs. In the events, promos and service information were also included as promotional materials. This 
was confirmed by informant A, Head of Marketing Public Relations of PELNI Jakarta Hospital. "And for the patients, we held small seminars if there are big days like yesterday, in order to commemorate the world eye day we gave an explanation about eyes and opened Question and Answer session in front of the poly eye, but we also tuck in small promos inside to attract patients. But, it doesn't always have to be every national or international big day depending on the program. And also we have an annual event that is also mandatory. "

This is also strengthened by informant $\mathrm{C}$, as one of the Public Relations Marketing Staffs of PELNI Jakarta Hospital about. What events were held and followed, that "for our program there are promotions in every major day, for example on the heart's day offered medical check-up promo, big events like hospital expo and IBD Expo (Indonesia Business and Development)"

\section{B. Social media}

For Marketing Public Relations programs, PELNI Jakarta Hospital is more active in social media to establish closeness with customers and provide a faster response if there is a question from the customers. This is explained by (informant A) the Head of the MPR Section of PELNI Jakarta Hospital, that "participate in activating our social media such as Facebook, Twitter, web and Instagram. But the most active one is Instagram because now it's a trend, so many of the accounts are more active".

Related to the Marketing Public Relations programs of Jakarta PELNI Hospital, comparing the institution through social media, it was also reinforced by (informant B). As coordinator of PELNI Jakarta Hospital, he mentioned that "I think what I see is Marketing Public Relations of PELNI Jakarta Hospital, those running are like Instagram social media promos, but through Instagram we also handle questions and complaints from patients. So, Instagram or social media not only becomes a promotional forum but also a customer care media so there is a combination between the two. This was the method of marketing and the method of public relations. This was also strengthened by the statement of informant C, Marketing Public Relations staff at PELNI Jakarta Hospital. He stated that " also active social media rich, we post a day at least 2 times in the morning and evening and the content we work with our doctors have. The goal is to attract many followers and be easy to disseminate information. The problem is that our followers are still around 2,100. and we sometimes make live video Instagram with specialist doctors for questions and answers about illness directly with experts. "

\section{Evaluation}

In this case, the Marketing Public Relations division of the Jakarta PELNI Hospital conducted an evaluation to identify customer satisfaction level in relation to the distribution to several existing units. This was conveyed by Informant $\mathrm{C}$ as Marketing Public Relation staff at PELNI Jakarta Hospital

"We also measure customer satisfaction with a questionnaire distributed to all units such as outpatient care, hospitalization, IGD and other supporting units. Distribution was done by following the patient's action in compulsory filling out the questionnaire before going home, collected every week to the MPR division after that our division manages the results by manually calculating all the existing questionnaires and managing the percentage of satisfaction, our standard for calculating customer satisfaction must be above $80 \%$, it is stated satisfied, and we read one critique and suggestions. one if there is something that looks very uncomfortable then we will immediately clarify to the patient and ask by phone actually what happened and after that we evaluate the results and correct what is the patient's dissatisfaction is in which unit is evaluated and continues to the level satisfaction according to standard "

\section{Customer Relations}

In establishing customer relations, Marketing Public Relations PELNI Jakarta Hospital conducted a number of things, such as answering complaints quickly so that patients feel more cared for, getting a good response and paying attention to their complaints, making visits so that providers always remember PELNI Jakarta Hospital, making line active 24 hours to maintain easier communication and assisting services within the PELNI Jakarta hospital. This is in accordance with the statement by informant A as the Head of Marketing Public Relations of PELNI Jakarta Hospital, "Our programs related to customer relations are several, one of which is a visit to hospitals, community health centers and some to other providers including from company and insurance. So that we continue to build relations and make MOUs and good services and also we exchange contacts, so if there are difficulties from customers we can contact 24 hours so we can help internally. " The explanation was clarified by informant B as the coordinator of PELNI Jakarta Hospital that "in maintaining a strong relations relationship with partners we make a strategy that we usually call a case manager, that is, we give the Marketing Public Relations Division number to the PIC of the company, and partners if they have difficulties or need help when visiting the Jakarta PELNI Hospital can contact us so that we can help condition with the relevant units, even up to 24 hours, if they have difficulties we are ready to help to gain the trust of our partners. "

\section{E. Sponsorship}

In this case, the Marketing Public Relations of PELNI Jakarta Hospital is also active in providing sponsorship to companies as a means of promoting assistance directly to its target. This is supported by the Head of Marketing Public Relations at PELNI Jakarta Hospital. "Then we often open health talk to companies that need us to bring our specialist doctors and also inform our hospital services and of course we tuck in promos. We also have an onsite MCU. There is also our opportunity while providing the best service and also informing what services are in the PELNI Hospital ". The explanation was given in an interview with one of the Marketing Public Relations staffs at PELNI Jakarta Hospital "health talk to companies while mini check-ups, so while we provide services while educating students"

\section{F. Promotions}

In the case of promotion programs for almost every activity Marketing Public Relations PELNI Jakarta Hospital leads to promotion either through social media or to direct customers. As explained by informant A as the Head of Marketing Public Relations at PELNI Jakarta Hospital. "For the patients, we make small seminars if there are big days like 
the world eye day we give an explanation about the eyes and open the FAQ before poly eye, but we also tuck in small promos to attract patients. But it doesn't always have to be every national or international big day depending on the program. And also we have an annual event that is also mandatory. Then, we also often open health talk to companies that need us to bring our specialist doctors and also inform our hospital services and of course we tuck in promos. And we also have an onsite MCU where we also have the opportunity to provide the best service as well as inform what services are in PELNI Hospital, and activate our social media such as Facebook, Twitter, web and Instagram. But the most often active is Instagram because now it's a trend so the account is also more active, many ask. "

The informant B as the coordinator of the Marketing Public Relations division of PELNI Jakarta Hospital mentioned that "if I think what I see from my eyesight Marketing Public Relations that has been running is like Instagram social media promos". Clearly with the statement from the Marketing Public Relations Staff of PELNI Jakarta Hospital informant $\mathrm{C}$ As a staff of the Marketing Public Relations division of Jakarta PELNI Hospital that " for the program we have promotions every big day, for example on the day of the heart makes a heart check-up promo, event big events like hospital expo and IBD (Indonesia Business and Development) expo, seminars at health centres, health talk to companies while mini medical check-up, so while we provide services while educating students. And also active social media for example, now we post a day at least 2 times in the morning and evening and we are working together with the doctors we have. "

\section{G. Advertising}

In advertising the PELNI Jakarta Hospital, the marketing public relations also plays an active role in both print and online media to expand its name more broadly. In this case PELNI Hospital Coordinator explained, that. "Maybe later we will go to TV, enter magazines that are indeed the target of the middle up. It is confirmed by the statement of informant $\mathrm{C}$ as MPR Staff at PELNI Jakarta Hospital, "creating articles in magazines like we have in woman review magazines and tempo magazines, and we have also been interviewed online by some rich online media detik.com, monitors .co.id, beritasatu.com, and tribunnews.com as far as I remember it is Miss, but there are many more. "

\section{CONCLUSION}

Based on the results of the discussion, it can be concluded that the marketing public relations program creates the brand image of PELNI Jakarta Hospital through various activities such as annual event events such as Hospital Expo and events as needed, to create lay seminars for patients on national and international holidays. In terms of Social Media campaigns, PELNI Jakarta Hospital is more active in filling social media contents such as updating 2 (two) times a day with different contents as needed and promotions as well as actively answering if there are questions that arise on social media. The third is evaluation by distributing questionnaires to all existing service units with $80 \%$ satisfaction standard.

Fourth, Customer relations, in this case the Marketing Public Relations of PELNI Jakarta Hospital maintains relations by handling complaints quickly, making a visit to the provider or record and provide easy contact for 24 hours. The fifth is sponsorship by filling out health talk shows and giving free checks to companies. Sixth, promotions were done by always giving discounts on national and international holidays. The seventh is advertising. In this case, the Marketing Public Relations of PELNI Jakarta Hospital advertises in printed media such as Woman Review magazine and actively attends interview sessions with online media. The conclusion of this study is that all of these programs are carried out continuously by Marketing Public Relations of PELNI Jakarta Hospital to create a brand image.

\section{REFERENCES}

[1] R. Ruslan, Manajemen Public Relations dan Media Komunikasi, Jakarta: Raja Grafindo Persada, 2016.

[2] F. Rangkuti, Strategi Promosi Yang Kreatif, Jakarta: PT Gramedia Pustaka Utama, 2009.

[3] P. a. K. L. K. Kotler, Marketing managemen, 12thEdition, New Jersey: Pearson Education, $2006 .$.

[4] D. A. A. B. A. L. B. E. \&. A. Aaker, Advertising's Role In Building Strong Brands, New Jersey: Lawrence Erlbaum Associates, Inc, 1993.

[5] S. B. a. D. L. G. Davis, Quality management: introduction to total quality management for production, processing, and services. 3rdEdition, New Jerse:: Prentice Hall, 2000.

[6] J. W. Creswell, Research Design, Yogyakarta: Pustaka Pelajar, 2016.

[7] J. W. Creswell, Penelitian Kualitatif \& Desain Riset, yogyakarta: Pustaka Pelajar, 2014.

[8] D. L. J. Moleong, Metodologi Penelitian Kualitatif,, Bandung: PT Remaja Rosdakarya, 2016. 